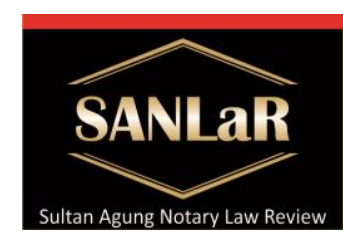

Volume 2 No. 4, December 2020
Sultan Aqung Notary Law Review

Code of Ethics and Position of Notary in Indonesia (Ong Argo Victoria)

\title{
Code of Ethics and Position of Notary in Indonesia
}

\author{
Ong Argo Victoria*), Ade Riusma Ariyana ${ }^{* *}$ and Devina Arifani ${ }^{* * *}$ \\ *) International Researcher of International Islamic University Malaysia (IIUM), E-mail: \\ argovictoriaupin@gmail.com \\ ${ }^{* *}$ Student of Master of Law, University of Semarang (USM), E-mail: \\ aderiusma@gmail.com \\ ${ }^{* * *}$ Student of Islamic Law, FAI, Sultan Agung Islamic University Semarang (UNISSULA), \\ E-mail: devinaarifani12@gmail.com
}

\begin{abstract}
The notary is authorized to make authentic deeds regarding all actions, agreements and provisions required by the laws and regulations and/or that the interested party wants to be stated in the authentic deed, guarantees the certainty of the deed creation date, keeps the deed, provides grosse, copies and excerpts of the deed, all of them as long as the deeds are drawn up, they are not assigned or exempted from other officials or other people as stipulated by law. Therefore, the general power (openbaar gezaag) based on the law assigns the officer concerned to produce written evidence as desired by the parties with authentic power. The approach method used in this study is primarily a descriptive analysis approach. In practical terms, By writing this research, it is hoped that it can provide valuable input for all parties involved in the implementation of the notary office and can also add insight to the notary regarding the problem of violating the code of ethics which results in criminal action. What is stated in the notary code of ethics made by the INI organization which is the only notary organization that is legally incorporated in accordance with UUJN. This means that all notaries must comply with the Notary Code of Ethics. What is stated in the notary code of ethics made by the INI organization which is the only notary organization that is legally incorporated in accordance with UUJN. This means that all notaries must comply with the Notary Code of Ethics. What is stated in the notary code of ethics made by the INI organization which is the only notary organization that is legally incorporated in accordance with UUJN. This means that all notaries must comply with the Notary Code of Ethics.
\end{abstract}

Keywords: Code of Ethics; Notary Public; Law.

\section{Introduction}

The legal certainty besides the authenticity of a deed, namely have the power of proof, namely outwardly, formally and material including ethics of a notary in carrying out his position. In carrying out their duties, the Notaries are not only carry out the work mandated by law onlyat the same time carrying out a very important social function, namely being responsible for carrying out the trust given to the general public they serve, a Notary must adhere to the Notary's Code of Ethics, but in reality, there are still notaries who violate the Notary's code of ethics. Besides that, the rules that bind each of its members have not been implemented properly. In certain fields, the government through law is assigned and entrusted with the Notary and vice versa the public must also believe that the Notary Deed was made provide legal certainty for its citizens, according to the sound Article 15 paragraph 1 of Act No. 30 of 2004 jo. Act No. 4 of 


\section{4 concerning Position Notary Public ${ }^{1}$.}

In Article 4 of Act No. 30 of 2004 jo. Act No. 4 of 2014 concerning the Position of Notary Public, it is stated that before carrying out his position, the Notary is obliged to take an oath, among others, to carry out his position in a trustworthy, honest manner, maintain attitude, behavior and carry out obligations in accordance with the code of professional ethics, honor, dignity. and is responsible as a Notary Public, thus the behavior of Notary $X$ as mentioned above is very contrary to the content of the article stated.

The Notary Code of Ethics is made to maintain the honor and dignity of the notary office which contains moral principles that must be adhered to by every member of the association which has been regulated, either in Staatsblad 1860 Number 3 or in Article 89 of the Law on Notary Position Number 30 of 2004 concerning the following Notary Positions the sanctions that will be given if a member commits a violation. The existence of a code of ethics aims to make a profession run professionally with motivation and orientation towards intellectual skills and to argue rationally and critically and uphold moral values. Notary services as part of service to the community must run parallel to the development of society in the future. Accuracy, speed and proficiency of notaries, not only based on a formalistic perspective, but must be based on a professionalistic perspective, so that efforts to improve the quality of notary services actually bring positive results for society.

\section{Research Methods}

The approach method used in this study is primarily a descriptive analysis approach. Descriptive analysis is research that describes an analysis of existing findings. The analytical descriptive approach in this study is an approach in terms of Legislation and Legal Norms in accordance with existing problems.

\section{Results and Discussion}

\subsection{Definition of Ethics}

Based on the meaning in the Big Indonesian Dictionary, ethics can be formulated, namely:

1. Moral values and norms held by a person or group of people in society to regulate their behavior.

2. Ethics also means a collection of moral principles or values.

3. Ethics can also be understood as the science of good and bad.

Ethics is a critical, methodical, and systematic reflection on human behavior as far as norms or human behavior are concerned from a good and a bad angle.

In carrying out his position, Notary Public must comply with all moral principles that have lived and developed in society. In addition to responsibility and professional ethics, integrity and good morals are important requirements that must be possessed by a notary public, because responsibility and professional ethics have a close

\footnotetext{
${ }^{1}$ Act No. 30 of 2004 jo. Act No. 4 of 2014 concerning the Position of Notary Public
} 
relationship with integrity and morals. "Professional Ethics are norms, terms and conditions that must be met by a group of people who are referred to as professionals". To be able to carry out their duties properly in providing services to the community, a professional must carry out his position by aligning his expertise with upholding the professional code of ethics.

\subsection{Professional Code of Ethics}

Professional code of ethics is a product of applied ethics because it is generated based on the application of ethical thinking to a profession. "Professional code of ethics can change and be changed along with the development of science and technology so that members of professional groups will not be outdated. Professional code of ethics is the result of professional self-regulation that is concerned, and this is the manifestation of essential moral values, which are not imposed from outside. This code of ethics is only effective if it is animated by the ideals and values that live within the profession itself. A professional code of ethics is a formulation of human moral norms that carry out The professional code of ethics is a measure of the actions of members of the professional group.Professional code of ethics is an effort to prevent unethical acts by its members.

A code of ethics needs to be formulated in writing, according to Sumaryono in his book on Legal Profession Ethics, Norms for Law Enforcers, states the reasons:

1. as a means of social control

2. as a deterrent to interference from other parties

3. as a prevention of misunderstanding and conflict

Basically, a code of ethics for protection is a norm of behavior that is already considered correct or that is already established and of course it will be even more effective if the applicable norm is well formulated, so as to satisfy the parties concerned. Professional code of ethics is a crystallization of behavior that is considered correct in public opinion because it is based on considerations of the interests of the concerned protection. Thus the professional code of ethics can prevent misunderstandings and conflicts, and on the contrary serves as a reflection of the good name of the protection. A good protection code of ethics is one that reflects the moral values of members of the professional group themselves and those who need the relevant protection services ${ }^{2}$.

\subsection{Notary Profession}

Notaries who have a role and activities in the pre-profession of law cannot be separated from the fundamental problems related to the function and role of the law itself, where law is defined as the rules that govern all the life of the community, more broadly the law functions as a tool for community reform. .

Indonesia as a developing and developing country, the role and function of the law for a legal preamble is not easier than in a developed country, because there are various

\footnotetext{
${ }^{2}$ Nofita S., Putri, Chalim, Munsharif A., \& Setyawati. (2020). Legal Protection Against Substitute Notary in Semarang Based on Act No. 2 of 2014 Amendment Act No. 30 of 2004 jo. Act No. 4 of 2014 concerning Notary. JURNAL AKTA: Vol.7, No. 2, 195-200. Retrieved from http://jurnal.unissula.ac.id/index.php/akta/article/view/7901
} 
limitations that not only reduce the smoothness of the legal process in an orderly and definite manner but also require approaches and ideas thoughts that lead to an adaptive legal construction that can balance various existing interests steadily ${ }^{3}$.

There is an ability to uphold the legal profession which requires personal integrity and professional skill and that can be described;

1. In depth, the ability to be responsive and uphold public interests, namely upholding professional standards as a good and responsive legal servant. behave individually. able to show the characteristics and actions that are suitable for a good servant of law,

2. Exit. the ability to be responsive to the development of society and its environment, uphold the interests of the general public, be able to accommodate, adapt and develop legal norms and their application in accordance with the demands of the development of society and technology.

\subsection{Notary History}

The history of the notary institute dates back to the 11th or 12th century in the Central Italian trade area. In the 13th century the notarial institution reached the peak of its development, after that in the 14th century there was a decline in the notarial field, this was due to the actions of the rulers at that time who seemed to sell Notary positions to people regardless of whether the person had expertise or not, causing a lot of complaints from the public.

At the beginning of the 19th century, this notarial institution expanded to the surrounding countries and even to other countries. At the peak of its development and after the institutionalization of the notariat, this institution was brought by the Dutch with two imperial decrees, namely on November 8, 1810 and March 1, 1811 which were valid throughout the Netherlands.

The legislation of the French notariat that was enacted in the Netherlands did not immediately disappear even though the country had been released from French rule, after repeated pressure from the Dutch people to form a national legislation in accordance with the aspirations of the people in the field of notariat, then on July 9 , 1842, a Law on the Position of Notary was issued, namely the Netherlands Staatblad Number $20^{4}$.

The historical development of the notariat in the Netherlands is very important for the notariat institution in Indonesia. The notariat in the Republic of der verenigde Nederlanden began to enter Indonesia at the beginning of the 17th century.

In 1860 the regulations regarding the position of a Notary in Indonesia were adjusted to the laws in force in the Netherlands with the enactment of Staatblad Number 3 Concerning Rules for the Position of Notary Public on January 26, 1860 which came into effect on July 1, 1860, with the promulgation of "Notary Public Reglemen ", then a strong foundation is laid for the institutionalization of the notariat in Indonesia.

\footnotetext{
${ }^{3}$ Abdulkadir Muhammad. (1997). Etika Profesi Hukum. Bandung: Citra Aditya Sakti. p.45

${ }^{4}$ GHS Lukman Tobing. (1999). Peraturan Jabatan Notaris. Jakarta: Erlangga. p. 76
} 
In line with the changing times and the legal needs of the Indonesian people, the various provisions in the laws and regulations mentioned above are no longer appropriate, it is necessary to carry out a comprehensive renewal and rearrangement in one law regulating the position of a Notary, so that a legal unification can be created. which applies to all residents throughout the territory of the Republic of Indonesia. In order to realize the legal unification in the notary field, on October 6, 2004, Act No. 30 of 2004 jo. Act No. 4 of 2014 concerning the Position of Notary was enacted.

\subsection{Notary Code of Ethics}

Notaries who practice in Indonesia join in an organizational association, namely the Indonesian Notary Association (INI). THIS is a continuation of De NederlandschIndische Notarieele Vereeniging, which was previously established in Batavia on 1 July 1908 which was approved as a legal entity with the Gouvernements Besluit (Government Declaration) dated 5 September 1908 Number 9. The Dutch name was later changed or changed to The Indonesian Notary Association, which until now is the only forum for professional organizations in Indonesia.

Then it received approval from the government based on the Decree of the Minister of Justice of the Republic of Indonesia on January 23, 1995 Number C2-1011.HT.01.06 of 1995, and it was announced in the State Gazette of the Republic of Indonesia dated April 7, 1995 Number 28 Supplement Number 1/P-1995, therefore as and is a Notary organization as referred to in UUJN number 30 of 2004 jo. Act No. 4 of 2014 concerning the Position of Notary which is promulgated in the State Gazette of the Republic of Indonesia of 2004 Number 117. According to Article 1 number (5) UUJN, it states that the Notary Organization is a professional organization for the position of a Notary which is formed by an association law ${ }^{5}$.

\section{Notary Personality Ethics}

As a general official, a notary must:
a. Have a Pancasila spirit;
b. Obey the law, oath of office and the Notary Code of Ethics;
c. Speak good Indonesian.
d. As professionals, Notaries must:
e. Have a professional behavior;
f. Participating in national development in the field of law;
g. Upholding the honor and dignity of the Notary.

Professional behavior is defined as fulfilling the following elements:

a. Skills that are supported by high knowledge and experience;

b. Moral integrity means avoiding something that is not good even though the reward for services is high, the implementation of professional duties is aligned with societal values, courtesy and religion;

c. Be honest not only with the second party or third party, but also to yourself;

\footnotetext{
${ }^{5}$ Komar Andasasmita. (1983). Masalah Hukum Perdata Nasional Indonesia. Bandung: Alumni. p. 81
} 
d. Not only consideration of money, but also dedication, does not distinguish between people who are able and unable;

e. adhere to the professional code of ethics because it defines all the behaviors that must be possessed by a Notary, including in perfect Indonesian.

\section{Ethics for performing job duties}

Notary as a general official in performing his/her job duties must:

a. Be aware of their obligations, work independently, are honest, impartial, and full of responsibility;

b. Using one office that has been designated in accordance with the law, does not hold a representative branch office, and does not use intermediaries;

c. Not using mass media that is promotional in nature;

d. Must put up a nameplate according to the prevailing size.

\section{Ethics of service to clients}

As a general official, a notary must:

a. Providing legal services to people who need the best possible services;

b. Completing the deed until the registration stage at the District Court and the announcement in the State Gazette, if the client in question clearly says that he will submit the arrangement to the Notary concerned and the client has met the necessary requirements;

c. Notifying the client regarding the completion of registration and announcement, and or sending to or ordering to take the registered deed or the State Gazette that has been finished printing by the client concerned;

d. Providing legal education so that people are aware of their rights and obligations as citizens and members of society;

e. Providing services to underprivileged members of society for free;

f. It is prohibited to hold someone's file with the intention of forcing that person to make a deed to the notary who is holding the file;

g. It is prohibited to become an instrument of another person or party to solely sign a deed made by another person as a deed made by the Notary concerned;

h. It is forbidden to send minuta to the client or clients to be signed by the client or clients concerned;

i. It is prohibited to induce or in any way force the client to make deeds to him, or persuade someone to move from another notary;

j. It is prohibited to form groups within the Indonesian Notary Association with the aim of serving the interests of an agency or institution specifically/exclusively, let alone closing the possibility of other members from participating.

\section{Ethics of relations among Notary colleagues}

As fellow public officials, a Notary must:

a. Mutual respect in a family atmosphere; 
b. Not doing competition that is detrimental to fellow Notaries, both morally and materially;

c. Must protect and defend the honor and good name of the Notary Corps on the basis of solidarity and constructive help.

\section{Supervision Ethics}

a. Ethical supervision of Notaries through the implementation of the Notary Code of Ethics is carried out by the Regional Honor Council and/or the Central Honorary Council of the Indonesian Notary Association;

b. The procedures for implementing the code of ethics, sanctions and execution are regulated in separate regulations;

c. Without prejudice to the provisions regarding the procedure or imposition of levels of sanctions in the form of warnings and warnings, violations ${ }^{6}$ which the Central Executive must absolutely be subject to temporary dismissal as a member of the Indonesian Notary Association accompanied by a proposal by the Central Executive to the Congress to dismiss the member concerned are violations mentioned in the Notary Code of Ethics and the Position of Notary Public which resulted in the member being found guilty based on a court decision that has obtained permanent legal force.

\subsection{Law Enforcement Code of Ethics of Notary Public}

The definition of law enforcement can be formulated as an effort to implement the law properly, supervise its implementation, and if there is a violation, restore the law so that it is re-enforced. Law enforcement is carried out by law enforcement according to the following sequence:

a. Warning warning to stop the violation and don't do it again

b. Imposing certain obligations (compensation, fines)

c. Allowance or exclusion (deprivation of certain rights)

d. Imposition of corporate sanctions (imprisonment, death penalty) In carrying out law enforcement duties, law enforcers are obliged to obey established norms.

Enforcement of the Notary's code of ethics is an effort to implement the Notary's code of ethics properly, to supervise its implementation so that there is no violation, and if there is a violation restoring the violated code of conduct so that it is re-enforced. Law enforcement of the Notary Code of Ethics is listed in Chapters IV and V, namely from Article 6 to Article 13. Which includes: "Sanctions, Supervision, Examination and Imposition of sanctions, Examination and Imposing of Sanctions at the First, Appeal and Last Level, Execution of sanctions in violation of the Code of Ethics".

\subsection{Supervision}

It is hoped that the authorization of the Notary Position Law will serve as a guidance institution so that Notaries in carrying out their positions can further improve the

\footnotetext{
${ }^{6}$ Jaya, Hendro K., \& Purnawan, Amin. (2020). Review Of The Implementation Process Of Completion Of Juridical Code Violations of Notary In Kendari. JURNAL AKTA: Vol.7, No. 2, 169-176. Retrieved from http://jurnal.unissula.ac.id/index.php/akta/article/view/7881
} 
quality of service to the public. In Article 67 paragraph (5) UUJN, what must be monitored is the Behavior of Notary Public and Implementation of Notary Position.

Notary supervision is regulated in Articles 67-81 of the UUJN, in which the supervision is carried out by the Minister and in carrying out such supervision the Minister shall appoint the Supervisory Council, which consists of the Regional Supervisory Council, the Regional Supervisory Council and the Central Supervisory Council. The Supervisory Council consists of 3 elements, namely elements from the Government, Notary organizations and academics ${ }^{7}$.

\section{a. Regional Supervisory Council (MPD)}

MPD conducts regular supervision every 6 months by checking the Notary's protocol ${ }^{8}$, giving permission to leave for 6 months and examining reports or complaints from the public against Notaries. If there is a complaint from the public against a Notary who violates the code of ethics or violation of the Law on the position of Notary Public, the MPD has the authority to hold a closed session for the public, the MPD will examine and hear the reporter's statement, the reported response, examine the evidence submitted by the reporter and the reported, then the results examination is contained in an examination report (BAP) and must be given to the Regional Supervisory Committee within 30 days with a copy to the notary concerned, the regional management of the Indonesian Notary Association and the Central Supervisory Council.

\section{b. Regional Supervisory Council (MPW)}

MPW has the authority to grant leave for 6 months to 1 year. Based on the BAP that has been given to MPW through MPD, MPW has the authority to conduct a Closed Examination Session for the public and a Decision Making Session which is open to the public. If the MPW Netarts examination session is not proven to have committed a violation, the BAP report is rejected and the notary is rehabilitated. If the notary is proven to have violated the decision, the decision must contain sufficient reasons and considerations which are used as the basis for making the decision.

MPW prepares an official report on every decision to impose sanctions, which is then submitted to the Minister, Reporters, Terrorists, MPD, MPP and the board of the Indonesian Notary Association. If the reported Notary has objected to the MPW trial decision, the Notary may file an appeal at the Central Supervisory Council level ${ }^{9}$.

\section{c. Central Supervisory Council (MPP)}

Authorized to grant notary leave for a period of more than 1 year. Following up on Notary who made an appeal submitted through MPW. MPP is obliged to conduct an Examination Session and Decision-Making Session which are open to the public.

\footnotetext{
${ }^{7}$ Liliana Tedjosaputro. (1995). Etika Profesi Notaris Dalam Penegakan Hukum Pidana. Yogyakarta: Bigraf Publishing. p. 12-13

${ }^{8}$ Fuditia, Megacaesa., \& Mashdurohatun, Anis. (2020). Protection Against Recipients Notary Deed That Allegedly Protocol To The Legal Issue In Semarang. JURNAL AKTA: Vol.7, No. 2, 177-182. Retrieved from http://jurnal.unissula.ac.id/index.php/akta/article/view/7888

${ }^{9}$ Suhrawardi K. Lubis. (1993). Etika Profesi Hukum. Jakarta: Sinar Grafika. p. 55
} 


\subsection{Violation of the Notary Code of Ethics}

Some examples of violations against UUJN committed by notary persons in making Notary deeds, namely:

a. The deed was drawn up without the presence of the witnesses, even though the deed itself was mentioned and stated "with witnesses present"

b. The deed in question was not read by the notary

c. The deed concerned is not signed in the presence of the Notary, even the minimum Deed is brought by another person and signed by and at a place unknown to the Notary concerned.

d. The notary makes the deed outside of his/her area of office, but the Notary concerned includes it in the deed as if it was administered in the jurisdiction of his/her jurisdiction or as if it was carried out at the domicile of the Notary.

e. A Notary opens a branch office by way of every branch in. at the same time carry out and produce Notary deeds as if all of the deeds were made before the Notary concerned.

The legal consequence of a deed made by a Notary who has violated the Law on the Position of Notary, namely, the said Notary is not authentic and the deed only has the power of a deed made under hand when signed by the parties concerned. Violations of the UUJN as exemplified above, which have resulted in losses to the public or users of Notary services, can be submitted by the public to the Regional Supervisory Council. Which then adjusted the mechanism to UUJN. The UUJN stipulates the sanctions in Articles 84 and 85 for violating the position of a notary public. The notary code of ethics which is regulated by the Notary organization, namely the Indonesian Notary Council (IN!) Is one of the recognized professional organizations for the position of Notary and has branches throughout Indonesia. Violations according to the Notary Code of Ethics are regulated in Article 1 number (9), namely: Violation is an act or action taken by an association or other person holding and carrying out a zeroaris position that violates the provisions of the Code of Ethics and/or organizational discipline.

\subsection{Penalty}

Sanctions in the Code of Ethics are listed in article 6:

1. Imposed on members who violate the Code of Ethics can be in the form of:
a. warning
b. instruction
c. schorsing (temporary dismissal) from association membership
d. onzetfing (dismissal) of association membership
e. Disrespectful dismissal from membership of the Association

2. The imposition of the senksi-senksi as described above against members who violate the code of ethics shall be adjusted to the quality of the violations committed by members. 
Referred to as sanctions is a punishment that is meant as a means, effort and means of enforcing obedience and discipline for members of an association as well as other people who take and carry out the position of a Notary in enforcing the code of ethics and organizational discipline. The imposition of sanctions on members who violate the Notary's code of ethics is carried out by the Honorary Council which is a tool for the association which is authorized to examine violations of the code of conduct including imposing sanctions on violators in accordance with their respective authority (contained in Article B). Notary violations are carried out by the Notary organization, namely the Indonesian Notary Association (INI), of its members, which directly control Notaries by the Honorary Council, which is in Article 1 point (8) of the Notary Code of Ethics. Honorary Council is a tool of equipment of the Association as; an agency or institution that is independent and free from partiality in the Association which is assigned to:

a. carry out coaching, guidance, supervision, and arrangement of members in upholding the Code of Ethics,

b. examine and make decisions on suspected violations of the provisions of the code of ethi: which are internal in nature or which have no direct connection with public interests

c. provide suggestions and opinions to the Supervisory Board regarding the alleged budget for the code of ethics and the position of a Notary

The Honorary Council examines and makes decisions on alleged violations of the provisions of the code of ethics which are "internal" in nature or which do not have direct connection with the interests of the community (article 1 paragraph 8 part a)

The examination and imposition of sanctions at the first level are carried out by the Regional Honorary Council which will only determine its decision regarding whether or not a violation of the code of ethics is proven or not and the imposition of sanctions against the violator, after hearing the statement and self-defense of that need. If the verdict of the regional honor council is proven to have violated the code of ethics, then the trial will simultaneously "determine sanctions" against the violators. (Article 9 paragraph (5). In the case of temporary dismissal as stipulated in article 13 . In the case of the imposition of sanctions for temporary dismissal (schor sing) as well as sanctions onzetting or disrespectful dismissal as a member of the association for violations as referred to in Article 13 above, the Central Executive shall notify the Supervisory Council. Regions (MPD) and a copy thereof submitted to the Minister of Law and Human Rights.

\section{Closing}

\subsection{Conclusion}

Notary is a public official who makes the authentic deed required by the community. Responsibility for the position is needed, so that a notary institution is needed to regulate the behavior of the notary profession. In essence, the Notary's Code of Ethics is a further explanation of what is regulated in the Law on Notary Office, considering that Notaries in carrying out their positions must submit to and obey all the provisions in the Law that govern their positions. What is stated in the notary code of ethics made 
by the INI organization which is the only notary organization that is legally incorporated in accordance with UUJN. This means that all notaries must comply with the Notary Code of Ethics.

\subsection{Suggestion}

Based on the description of the obligations and prohibitions as detailed above, it is hoped that the notary in carrying out his position will always reflect on the moral ethics of the profession that he carries, obey the principles, and obey and obey every regulation that governs his position so that society and all circles can truly interpret the profession notary as a noble and dignified profession.

\section{References}

Journal:

[1] Jaya, Hendro K., \& Purnawan, Amin. (2020). Review Of The Implementation Process of Completion Of Juridical Code Violations Of Notary In Kendari. JURNAL AKTA: Vol.7, No. 2, 169-176. Retrieved from http://jurnal.unissula.ac.id/index.php/akta/article/view/7881

[2] Fuditia, Megacaesa., \& Mashdurohatun, Anis. (2020). Protection Against Recipients Notary Deed That Allegedly Protocol To The Legal Issue In Semarang. JURNAL AKTA: Vol.7, No. 2, 177-182. Retrieved from http://jurnal.unissula.ac.id/index.php/akta/article/view/7888

[3] Nofita S., Putri, Chalim, Munsharif A., \& Setyawati. (2020). Legal Protection Against Substitute Notary in Semarang Based on Act No. 2 of 2014 Amendment Act No. 30 of 2004 jo. Act No. 4 of 2014 concerning Notary. JURNAL AKTA: Vol.7, No. 2, 195-200. Retrieved from http://jurnal.unissula.ac.id/index.php/akta/article/view/7901

Books:

[1] Abdulkadir Muhammad. (1997). Etika Profesi Hukum. Bandung: Citra Aditya Sakti

[2] GHS Lukman Tobing. (1999). Peraturan Jabatan Notaris. Jakarta: Erlangga

[3] Komar Andasasmita. (1983). Masalah Hukum Perdata Nasional Indonesia. Bandung: Alumni

[4] Liliana Tedjosaputro. (1995). Etika Profesi Notaris Dalam Penegakan Hukum Pidana. Yogyakarta: Bigraf Publishing

[5] Suhrawardi K. Lubis. (1993). Etika Profesi Hukum. Jakarta: Sinar Grafika Regulations:

[1] Constitution of 1945 Republic of Indonesia

[2] Act No. 30 of 2004 jo. Act No. 4 of 2014 concerning the Position of Notary Public 